\title{
Family Development Session of the Indonesian Family Welfare Program
}

\author{
Aan Annisa ${ }^{1, *}$, Hani Yulindrasari ${ }^{2}$ \\ ${ }^{1,2}$ School of Postgraduate Studies, Universitas Pendidikan Indonesia, Bandung, Indonesia \\ * Corresponding author. Email: aanannisa23@upi.edu
}

\begin{abstract}
Poverty is a problem that occurs in many countries including Indonesia. Program Keluarga Harapan (Family Welfare Program/FWP) encourages the community to increase their purchasing power by providing cash, and improve the families' access to health and education services. Family Development Session (FDS) is one of activities in the FWP aiming at changing the family's mindset and behaviour about the importance of children's health and education for a better future. Based on literature research, this paper reviews how the FDS could motivate the families to improve their welfare and future to break the intergenerational poverty chain. The review suggests that the success of FDS relies on the content and the facilitators of the program in delivering the content to the families. The review recommends further investigation on the modules of the FDS activities.
\end{abstract}

Keywords: Hope family program (PKH), beneficiary families (KPM), family development session (FDS), prosperity.

\section{INTRODUCTION}

Poverty is a global problem needs to be addressed [1]. The world keep innovating a social safety net program that is more effective in combating poverty. In 2007, Indonesia launched a family welfare program called Program Keluarga Harapan (PKH)/ Family of Hope Program. PKH is an adaptation of the Conditional Cash Transfer (CCT) program [2]. Which is also implemented in several other countries such as Latin America, Mexico, Brazil, the Philippines and so on [3], [4], [5], [6], [7]. $\mathrm{PKH}$ as a conditional social assistance has rules or interventions for the recipients. So that the beneficiary family does not only receives cas assistance but also needs to follow certain requirements, such as agree to access health and education services [8], [9].

PKH becomes a mean to overcome maternal and children's health problem as well as the problem of education attainment of families with low social economic status [10], [11]. This is expected to be a supporting factor for children from the families to have a better future. With the aim of breaking the intergenerational chain of poverty, PKH launched an empowerment program in the form of a Family Development Session (FDS) which would be attended by all the beneficiary families of the PKH. This FDS activity is a program of structured learning activities conducted to improve understanding and awareness of the families on the importance of education and health to improve the quality of life [12], [13].

This article will discuss how this FDS activity can be the driving force for the families in improving their future welfare.

\section{FAMILY DEVELOPMENT SESSION (FDS)}

FDS activities are delivered for families participating in the PKH (Family Welfare Program) who are a transition (from on-assistance to off-assistance) period to mentor the families to be independent in improving their live condition. This FDS scheme is similar to community empowerment carried out by Non-Government Organizations (NGOs) in the dissemination process. In the process of its development FDS had been piloted in several district. The pilot project was by the Ministry of Health and the Ministry of Social Affairs in collaboration with UNICEF at 2007 [14].

In 2018 FDS which was also called the Family Capacity Building Program have five main training modules on five different aspect of family welfare, which are education and childcare, health and nutrition, family financial management, child protection, and social welfare. These modules are used as a reference by the facilitator to be delivered to the families during the implementation of FDS [2], [15], [16], [17], [18], [19]. 
Each module has sessions and steps that are arranged sequentially to make it easier for the facilitator in delivering FDS material.

FDS activity is carried out once a month by the social worker as a tutor/facilitator and the families as participants. The learning approach used is an andragogical approach so that it does not appear to be patronizing and instead there is more dialogue between the families and the facilitator [20]. This FDS can also be conducted in an informal and convenient atmosphere anywhere based the agreement of the group of families and the facilitator it is not confined to one place/space like a conventional classroom-based training [21]. Many times, the FDS activities has become a space for the families to share their daily problem with one another. Therefore, FDS activity not only a space for the families to get knowledge and information from the facilitator also a space of dialogue and collaboration among the families to and find solutions to their problems together [12].

The FDS is implemented in several stages: planning, implementation and reporting. The first stage consists of training for FDS facilitators. Following the training, then the facilitator will form a group of families consist of 40 people. The FDS program is conducted once a month to each group with a duration of 120-150 minutes per sessions [22], [23], [24]. The second stage is the implementation stage. The implementation consists of the delivery of teaching and learning materials in the form of modules for the facilitator, smart books for the families, flipcharts, videos, brochures, pamphlets and so on. The modules are systematically delivered from module one to module five [24].

The first module is about childcare and education. This module aims at improving parents understanding about the importance of parenting and how it affects children. Parents play an important role in supporting children's education. The module empowers the families that their economic condition is not a barrier to better parental care. The family is encouraged to be able to help children succeed in school [25], [26], [19].

The second module is about health and nutrition, the families is empowered to have an understanding of the importance of access to health services, especially for pregnant women and toddlers. As well as inviting the families to be more aware of environmental cleanliness and a healthy lifestyle starting from personal and family hygiene. In addition, it provides an understanding of the fulfilment of nutrition in children to avoid the risk of stunting and malnutrition in children [25], [26], [17].

The third module is about Financial Management and Business Planning. It is important to improve the families' economic capacity since financial problem often triggers family violence and other problem this module provide information on household financial management, including how to spend money effectively. The module also provide training on how to start a small business so that the families can be financially independent and free from social assistance. In addition, this module introduces banking services and products, such as how to use ATMs and Bank deposit/saving and other facilities available [25], [26], [17].

The fourth module is a module on child protection which complement module one on child care and education. The module provides knowledge about how to prevent violence against children. Preventing violence against children is very important to better support children's growth and development. The information is important because children from low social economic status are at risk of neglect and exploitation of children. The module explains what actions fall into the category of violence and invites people to avoid it [25], [26], [18].

The fifth module is about social welfare. This module aims at improving the live condition of the elderly and people with severe disabilities [25], [26], [16]. The five module are designed to be used as a reference and provide structured learning to accelerate changes in the families' mind set and behaviour and to make people aware of the importance of parental support for children's education and health [27].

Several studies show that FDS was successful in providing knowledge to the families on various matters regarding the problems faced by the families [28]. The FDS module has also been continually improved. The initial project of FDS only consisted of three module, the current version have five modules with more comprehensive coverage on the subject.

After the implementation of FDS, the assistant will report it via a form regarding the participation of the families in each FDS session [20]. Reporting is carried out in stages, starting from the assistant to the regional coordinator. What is reported is the number of welfare beneficiaries who have participated in the FDS for each session as well as an attached photo of the implementation activity. Along with the abundance of literature that shows the success of $\mathrm{PKH}$ in reducing poverty. FDS activities are also believed to be some of the driving forces capable of accelerating changes in the mindset of the families so that they consciously understand the importance of health and education which are expected to be the driving force for the families so that they can achieve greater welfare [29], [28].

\section{FAMILY DEVELOPMENT SESSION (FDS) IN OTHER COUNTRIES}

Apart from Indonesia, the implementation of FDSlike activities in the CCT program is also carried out in other countries. However, the terms and policies vary and the material is tailored to the needs of each country. However, generally speaking all are encouraged to 
maximize access to health and education such as in the Philippines with the Pantawid Pamilyang Pilipino Program (4P's). The 4P program also has topics that are discussed regarding health such as personal hygiene, prevention of malnutrition, prevention of cases of common childhood illnesses and reduction of incidence of health risks, waste management and backyard gardening [30].

According to several studies, it was stated that the 4P program and the implementation of FDS in the Philippines had a positive impact both on the understanding and behaviour of the beneficiaries which experienced a significant change in a more positive direction [31]. For the early childhood category, in the Philippines. However, the families are not only encouraged to be able to access health services. They are also encouraged to provide education services is a day care centre for their children. Their attendance is included in the verification of commitment [14].

Apart from the Philippines, Brazil through the Bolsa Familia program, they also have FDS-like activities that have been carried out to encourage the success of the program because Brazil in 2010 had a high population suffering from extreme poverty, namely 16.2 million people. So through this CCT program Brazil had the goal to be able to solve the problem of extreme poverty by 2014. There is a lot of literature that states that Brazil through its Bolsa Familia program was able to overcome these things well and the implementation of CCT was considered quite successful. However, in terms of beneficiary selection as well as education policy, it still has to be improved [32], [6], [33].

The same efforts were also made by Mexico through the PROGRESA program, encouraging access to education and health services so that it is able to cut the transmission of poverty between generations. Long before Indonesia implemented PKH, Mexico had implemented PROGRESA in 1997 with the main focus on pregnant women and early childhood where pregnant women were encouraged to check their pregnancies and undergo good parenting education and pay attention to early education. FDS was also implemented in Mexico with the same goal of encouraging changes in people's attitudes and mindsets [5], [34]. After FDS activities, the same reporting scheme was carried out by observing the presence of beneficiaries who access these services.

Apart from the countries above, there are still many other countries that implement social safety net designs such as CCT, either old or new. Generally speaking, all requirements focus on access to health and education services [35], because this is still the strongest consideration for long-term investment to be able to cut the transmission of poverty between generations. Thus, FDS activities carried out in these countries are activities with the same goal of providing knowledge to the beneficiaries about the importance of health and education [36], [37], [38].

\section{FAMILY WELFARE}

Good welfare is in is an ideal condition in a society in accordance with agreed standards and indicators in society [39]. A similar opinion also states in more detail that good welfare is the fulfilment of the physical, mental and social conditions of a society [40]. In Law Number 11 of 2009 concerning Social Welfare, it states that social welfare is a mandate of the realization of the 1945 Constitution and the fifth principle of Pancasila.

The problem of not achieving good social welfare according to Law Number 11 of 2009 states that the basic needs of citizens are not properly fulfilled because they have not received services from the State [41]. This results in a person not being able to live their life properly and with dignity. So, welfare is the fulfilment of one's basic needs so that they can live a decent life.

Social welfare has measurable indicators in that people can see the condition of the community at that times. This welfare indicator is what the United Nations Development Program (UNDP) calls the Human Development Index (HDI). HDI according to UNDP can be seen through three dimensions, namely life expectancy at birth, average education level and a decent life with purchasing power (Standard of Living) [42].

So if seen from the goals and objectives of $\mathrm{PKH}$, it really encourages the families to increase the three HDI indicators, namely through access to health and education services and providing cash assistance to increase purchasing power. Maximizing intervention is carried out with the existence of FDS, so that awareness of the importance of access to health and education services as well as parental support for children's development and behaviour can be better.

\section{CONCLUSION}

The Family hope Program or known as Program Keluarga Harapan (PKH) is a social safety net program that is currently considered the best according to several studies. One of the highlights at this time is the FDS. Through encouraging program commitment, namely access to health and education services. These two areas are considered as the most important investment to make in order to break the intergenerational chain of poverty, because many parties conclude that poor families have the potential to give birth to new poor families. If this is not handled seriously, the problem of poverty will continue to be a problem.

Through FDS activities, the families are encouraged to have awareness about the importance of access to health and education services for their children. With the available modules, the facilitator can provide much 
knowledge to the families, which is useful for solving several problems. In other countries which use the same program, they also have FDS activities with tailored materials in addition to health and education programs.

After conducting a literature review on FDS activities in $\mathrm{PKH}$, the overall system is quite good. However, there are two things that researchers see that need to be considered. First, an instrument for assessing the behaviour of the families who have participated in FDS should be developed, so that the increase in the number of welfare beneficiaries is not only seen from the attendance of the families during FDS activities. Second, due to the strength of FDS meetings, apart from the role of companion, information gained can also be used as a reference [44]. So it is necessary to do a more in-depth study so that the impact of FDS activities can be more measured as a driver for the families to achieve good welfare in the future.

\section{REFERENCES}

[1] Utomo, D. Pelaksanaan program keluarga harapan dalam meningkatkan kualitas hidup rumah tangga miskin (Studi pada unit pelaksana program keluarga harapan kecamatan Purwoasri Kabupaten Kediri). Jurnal Administrasi Publik. 2014;2(1):29-34. Available from: https://doi.org/ 333-2287-1-PB.

[2] Mulia RA, Saputra, N. Analisis faktor-faktor yang mempengaruhi kesejahteraan masyarakat kota Padang. Jurnal EL-RIYASAH. 2020;11(1):67-83. Available from: http://dx.doi.org/10.22460/commedu.v2i1.2442.

[3] Adato M, Hoddinott J. Conditional cash transfers in Latin America. Washington, DC: International Food Policy Research Institute; 2010: pp.176-180.

[4] Fernandez L, Olfindo R. Overview of the Philippines' conditional cash transfer program: The Pantawid Pamilyang Pilipino Program (Pantawid Pamilya). Philippine Social Protection Note. 2011 May 1(2):1-12. Available from: http://documents1.worldbank.org/curated/en/31385 1468092968987/pdf/628790BRI0Phil0me0abstract 0as0no010.pdf.

[5] Gertler P. Do conditional cash transfers improve child health? Evidence from PROGRESA's control randomized experiment. American Economic Review. 2004;94(2):336-41. DOI: 10.1257 /0002828041302109.

[6] Soares FV, Ribas RP, Osório RG. Evaluating the impact of Brazil's Bolsa Familia: Cash transfer programs in comparative perspective. Latin American Research Review. 2010;45(2):173-90. Available from: https://www.jstor.org/stable/ 27919200.

[7] Tabuga AD, Reyes CM. Conditional cash transfer program in the Philippines: Is it reaching the extremely poor? PIDS Discussion Paper Series No. 2012-42. Makati City: Philippine Institute for Development Studies (PIDS).

[8] Kementerian Sosial, RI. Pedoman umum program keluarga harapan. Jakarta: Kementrian Sosial Republik Indonesia; 2015.

[9] Nazara S, Rahayu, SK. Program keluarga harapan (PKH): Program bantuan dana tunai bersyarat di Indonesia. [Internet]. International Policy Centre for Inclusive Growth. 2014 Jan. Available from: https://ideas.repec.org/p/ipc/pbbaha/42.html.

[10]Daud M, Marini Y. Implementasi program keluarga harapan dalam meningkatkan kesejahteraan masyarakat miskin. Jurnal Humaniora: Jurnal Ilmu Sosial, Ekonomi dan Hukum, 2018;2(1):29-38. Available from: https://doi.org/10. 30601/humaniora.v2il.51.

[11] Suleman SA, Resnawaty R. Program keluarga harapan $(\mathrm{PKH})$ : Antara perlindungan sosial dan pengentasan kemiskinan. Prosiding Penelitian dan Pengabdian kepada Masyarakat, 2017;4:88-92. Available from: https://doi.org/10. 24198/jppm.v4i1.14213.

[12] Febrianto RA, RC, AR. Pengaruh peran pendamping dan motivasi belajar terhadap perubahan perilaku keluarga penerima manfaat (KPM) program keluarga harapan (PKH). Jurnal Ilmu Sosial dan Humaniora. 2020;9(1):99-110. Available from: http://dx.doi.org/10.23887/jishundiksha.v9i1.24505.

[13]Luthfi M. Efektifitas bantuan sosial program keluarga harapan dalam meningkatkan kesejahteraan keluarga (Studi kasus di Desa Margajaya Kecamatan Ngamprah KBB). CommEdu (Community Education Journal), 2019;2(1):8189. Available from: http://dx.doi.org/10.22460/ comm-edu.v2i1.2442.

[14] Arfiyani I, Raharjo TJ, Yusuf A. Family development session sebagai upaya peningkatan keterampilan hidup masyarakat miskin. Jurnal Ilmu Sosial dan Humaniora. 2020;9(1):57-67. Available from: http://dx.doi.org/10.23887/jishundiksha.v9i1.24517.

[15] Kementerian Sosial RI. Modul ekonomi. Jakarta: Kementerian Sosial RI; 2018.

[16] Kementerian Sosial RI. Modul kesejahteraan sosial. Jakarta: Kementerian Sosial RI; 2018.

[17] Kementerian Sosial RI. Kesehatan dan gizi. Jakarta: Kementerian Sosial RI; 2018.

[18] Kementerian Sosial RI. Modul perlindungan anak. Jakarta: Kementerian Sosial RI; 2018.

[19] Kementerian Sosial RI. Modul pengasuhan dan pendidikan anak. Jakarta: Kementerian Sosial RI; 2018. 
[20] Rahmawati E, Kisworo B. Peran pendamping dalam pemberdayaan masyarakat miskin melalui program keluarga harapan. Journal of Nonformal Education and Community Empowerment. 2017;1(2):161-169. Available from: https://doi.org/10.15294/ pls.v1i2.16271.

[21]Basleman A, Mappa S. Adult learning theory. Bandung: PT Remaja Rosdakarya; 2011.

[22] Tiffani AL. Pelaksanaan diklat pertemuan peningkatan kemampuan keluarga (P2K2) bagi pendamping PKH di BBPPKS Regional III Yogyakarta tahun 2019. Hanata Widya, 2019;8(3):11-21. Available from: https://doi.org/ 16288-35710-1-SM.

[23] Sutiaputri LF. Implementasi pertemuan peningkatan kemampuan keluarga (P2K2) program keluarga harapan (PKH) di komunitas adat Kampung Kuta, Desa Karang Paninggal, Kecamatan Tambaksari Kabupaten Ciamis. Jurnal Ilmiah Perlindungan \& Pemberdayaan Sosial, 2019;1(1):85-110. Available from: https://doi.org/674-1-10-20201014.

[24]Kementerian Sosial RI. Buku 8 petunjuk pelaksanaan pertemuan peningkatan kemampuan keluarga (P2K2) program keluarga harapan. Jakarta: Kementerian Sosial RI; n.d.

[25] Andina S, Tomlinson HB. PKH education team field visit report. Jakarta: Bank Dunia; 2012.

[26] Tomlinson HB, Andina S. Parenting education in Indonesia: Review and recommendations to strengthen programs and systems. Washington DC: World Bank Group; 2015.

[27] Sulistyaningsih E. Pola asuh orangtua pada peserta kegiatan pertemuan peningkatan kemampuan keluarga (P2K2) (Studi kasus pada keluarga penerima manfaat program keluarga harapan di Kelurahan Kebun Jayanti Kecamatan Kiaracondong Kota Bandung, Jawa Barat) [Doctoral dissertation, Universitas Pendidikan Indonesia]; 2019.

[28] Nurcahya F. Evaluasi program family development session di Desa Kebundalem Lor, Prambanan, Klaten (Studi survei di unit pelaksana program keluarga harapan Kecamatan Prambanan). Jurnal Elektronik Mahasiswa Pendidikan Luar Sekolah-S1. 2015;1(1):26-31.

[29] Kiswati A. Peran pendamping program keluarga harapan (PKH) dalam membantu meningkatkan kesejahteraan masyarakat miskin melalui kegiatan rutin pertemuan peningkatan kemampuan keluarga (P2K2) Kelurahan Blotongan, Sidorejo, Salatiga. [Bachelor thesis, Institut Agama Islam Negeri Salatiga]; 2020. Available from: http://erepository.perpus.iainsalatiga.ac.id/8451/1/JUH.pdf

[30]Zarsuelo M, Hurtada W, Suva M, Juanico S. Nutritional status of children and maternal knowledge, attitudes, and practices of conditional cash transfer (CCT) beneficiaries and nonbeneficiaries in Lucena City, Quezon, Philippines. International Proceedings of Chemical, Biological and Environmental Engineering. 2015;86(2):8-15. Available from: https://doi.org/10.7763/IPCBEE. 2015.V86.2.

[31] Rasella D, Aquino R, Santos CA, Paes-Sousa R, Barreto ML. Effect of a conditional cash transfer programme on childhood mortality: A nationwide analysis of Brazilian municipalities. The Lancet. 2013;382(9886):57-64. Available from: https://doi. org/10.1016/S0140-6736(13)60715-1.

[32] Nery JS, Pereira SM, Rasella D, Penna MLF, Aquino R, Rodrigues LC, Penna GO. Effect of the Brazilian conditional cash transfer and primary health care programs on the new case detection rate of leprosy. PLoS Neglected Tropical Diseases. 2014;8(11):e3357. Available from: https://doi. org/10.1371/journal.pntd.0003357.

[33] Fernald LC, Gertler PJ, Neufeld LM. Role of cash in conditional cash transfer programmes for child health, growth, and development: An analysis of Mexico's Oportunidades. The Lancet. 2008;371(9615):828-837. Available from: https://doi.org/10.1016/S0140-6736(08)60382-7.

[34] Das J, Do QT, Özler B. Reassessing conditional cash transfer programs. The World Bank Research Observer. 2005;20(1):57-80. Available from: https://doi.org/10.1093/wbro/lki005.

[35] Andina S, Tomlinson HB. PKH Parenting education program. Evidence paper. Jakarta: World Bank; 2013.

[36] Rawlings LB, Rubio GM. Evaluating the impact of conditional cash transfer programs. The World Bank Research Observer. 2005;20(1):29-55. Available from: https://doi.org/10.1093/wbro/lki001.

[37] UNESCO. Facilitators handbook for parenting education. Bangkok: UNESCO; 2011.

[38] Mulia RA, Saputra N. Analisis faktor-faktor yang mempengaruhi kesejahteraan masyarakat Kota Padang. Jurnal EL-RIYASAH, 2020;11(1):67-83. Available from: http://dx.doi.org/10.22460/commedu.v2i1.2442.

[39] Ndakularak E, Setiawina ND, Djayastra IK. Analisis faktor-faktor yang mempengaruhi kesejahteraan masyarakat kabupaten/kota di Provinsi Bali. Jurnal Ekonomi dan Bisnis Universitas Udayana, 2014;3(3):140-53. DOI: 7619-1-14192-1-1020140224.

[40]Undang-Undang Republik Indonesia nomor 11 tahun 2009 tentang kesejahteraan sosial. Jakarta: Republik Indonesia; 2009. 
[41] Yektiningsih E. Analisis indeks pembangunan manusia (IPM) Kabupaten Pacitan tahun 2018. Jurnal Ilmiah Sosio Agribis, 2018;18(2):32-50. Available from: http://dx.doi.org/10.30742/ jisa.v18i2.528.

[42] Lumbantoruan EP, Hidayat P. Analisis pertumbuhan ekonomi dan indeks pembangunan manusia (IPM) provinsi-provinsi di Indonesia (metode kointegrasi). Jurnal Ekonomi dan Keuangan. 2015;2(2):14-27. 